\title{
THE USE OF RUBRIC: AN OPPORTUNITY TO PROMOTE THINKING AND LEARNING
}

\author{
Agnes Herawati \\ Jurusan Sastra Inggris, Fakultas Bahasa dan Budaya, Bina Nusantara University \\ Jln. Kemanggisan Ilir III No. 45, Palmerah, Jakarta Barat 11480
}

\begin{abstract}
Article discusses the ways in which students perceive and use rubrics to support learning in the classroom. To further examine the impact of rubrics on students learning, this study conducted how rubrics gave impact on students learning, as well as whether using rubrics influenced the thinking ability of the students. In this study, 34 undergraduate students were provided rubrics for each of the two writing assignments assigned during the semester. At the end of the second assignment, students were asked about the use of rubrics as well as the relationship between rubric and performance. The students said that using rubrics helped them focus their efforts, produce work on higher quality and get better marks
\end{abstract}

Keywords: rubric, thinking skill, learning skill

\begin{abstract}
ABSTRAK
Artikel membahas cara mahasiswa memahami dan menggunakan rubric sebagai sarana pembelajaran di dalam kelas. Artikel berdasarkan sebuah penelitian yang bertujuan mengetahui dampak rubrik pada proses pembelajaran mahasiswa, dan dampak rubrik terhadap kemampuan berpikir mahasiswa. Responden terdiri 34 mahasiswa yang dibekali dengan rubrik ketika mengerjakan tugas mata kuliah menulis sebanyak dua kali. Di akhir tugas mahasiswa diminta menceritakan bagaimana dukungan rubric terhadap hasil tulisan mereka. Mahasiswa menjawab bahwa rubrik membantu mereka agar focus terhadap tugas, membuat tulisan dengan kualitas yang lebih baik, dan mendapatkan nilai yang lebih tinggi.
\end{abstract}

Kata kunci: rubric, ketrampilan berpikir, ketrampilan belajar 


\section{PENDAHULUAN}

Rubrics have become popular with teachers as a means of communicating expectations for an assignment, providing feedback and final mark (Andrade, 2000). A rubric is usually a one or two page document that describes a specific assignment. Moreover, rubric also means a document that articulates the expectation for an assignment by listing the criteria, or what counts, and describing levels of quality from excellent to poor (Andrade, 2000). See Appendix A for an example of an analytical rubric that fits this definition.

Many teachers use rubrics to mark students' works. However, actually rubrics can provide more than it. Rubric can teach as well as evaluate. In student-centered learning, rubric may help students develop a thinking process of how to succeed and also guarantee them of a dependable judgments about the quality of a work. Stiggins (2001) said that students are "the key assessment users (p17) and, should be able to use assessments in many of the same way that teachers use them - to clarify the standards for quality performance and to guide ongoing feedback about progress toward those standards. In other study, rubrics have been demonstrated to result in well-structured and welldefined assignments, and also serve to incorporate transparent formative assessment into a cycle of learning (Brookhart, 2002).

In Andrade and Du (2005), the authors explored the ways in which students perceive and use rubrics to support learning in the classroom. In their study, the authors used focus group to explore the ways in which a small group of students used rubrics and how rubrics gave impacts to their learning. Seven themes gathered from their analysis: communicating teacher's expectations, facilitating students' planning, facilitating revision and reflection, resulting equitable grading, improving quality of work, and lowering anxiety. Two points are considered in this study: facilitating students' planning and improving quality of work. However, it is important to expand on these two points and conduct further research on how rubrics give good impacts in promoting students' thinking and learning.

Rubric-referenced assessment is a process of formative assessment during which students reflect on the quality of their work, judge the degree to which it reflects the standards articulated in a rubric, and revise accordingly (Andrade, 2001). The emphasis here is on the word formative: the assessment is done on draft of works in progress in order to inform revision and improvement. The main subject in this assessment is the students themselves. However, this study is not merely focus on the self assessment conducted by the students, still teacher assessment based on the same rubric is done especially to provide feedback and to promote the improvement.

\section{Involving Teachers and Students in Assessment}

There is empirical evidence that students can and use rubrics to their advantages. In a study of the impacts of rubrics on eight grade students' writing and knowledge of the qualities of effective writing (Andrade, 2001) concluded that simply handling out and explaining a rubric was associated with higher scores on one out of three essays written by the students. Questionnaires administered at the end of the study revealed that students tend to focus their writing assignment on the criteria stated in the rubric.

However, a recent study by Hafner and Hafner (2003) provides additional evidence that undergraduate students can be effective users of rubrics. Their analysis on rubric-referenced peer evaluation of oral presentations in a college biologic class showed that student rating correlated highly with instructor rating. Hafner and Hafner conclude that rubric can become an effective strategy for teaching and learning in the context of a college science classroom. 
Additionally, the use of rubric in the classroom can be a tool to engage the more involvement of the teacher and especially the students on the assessment cycle. On the student side, there are three steps in involving students in the assessment (Gregory, Cameron, \& Davies, 2000). The first step is articulating expectation. The expectations for the task or performance are clearly articulated, either by the teacher, by the students or both together, perhaps by reviewing model assignment and/or cocreating a rubric.

The second steps related to critique of works in terms of expectations. Students create rough or first drafts of their assignment. They monitor their progress on the assessment by comparing their performances in progress to the expectations articulated in the rubric. They can do this by writing the reminder regarding the criteria should be improved in every progress until the last improvement in their final drafts.

The third and the final step is revising. In this step, students use the feedback from their selfassessment to guide revision. The revision step is crucial. Students are savvy, and will not self-assess thoughtfully unless they have the opportunity to channel their efforts toward improvement.

On the other side, teacher plays an important role in rubric-referenced assessment. In Andrade and Du (2005), seven themes are hoped from the teacher in this kind of assessment. They are: communicating teacher expectations, facilitating student planning, facilitating revision and reflection, resulting equitable grading, improving quality of work, and lowering anxiety. Moreover, a teacher needs to integrate the assessment cycle into teaching and learning.

Looking back at the impact of rubrics, however, it is important to explore further how students use rubrics to improve their thinking and learning as well as the role of rubrics in improving teacher's teaching strategies. This study sought to explore the impact of rubrics in encouraging students' thinking and learning.

\section{METHOD} learning.

This study sought to explore the impact of rubrics in encouraging students' thinking and

\section{Participants}

Thirty-four students of the English Advanced II class participate in this study. The course concentrated on topics including how to get good score in EPT and TOEFL tests. Rubrics were used to evaluate students' works on the two writing assignments required during the course. Students had access to the rubrics for each writing assignment and all the writing assignment were evaluated using the same rubric.

\section{Procedure}

Teacher and students used a rubric for each of the two writing assignments required for the course. The two writing assignment were similar in nature and the same rubric was used to evaluate those assignment. Students used rubrics during the peer assessment of the first assignment. They had to check their friends' works by using rubrics, show the strength and weaknesses of the works and gave feedback based on the criterion on the rubric. 
On the second assignment, rubric is distributed after the students wrote their first draft and they had to conduct self-assessment. Besides that, they also had to compare the result of their self assessment with the comment on the first assignment and found their points for improvement. After that, the second draft is done based on the points of improvement. As well as the end of the first draft, after the second draft, the students had to do self assessment, however at this time they also found how far they made improvements. The third draft is the final one. After the final draft, students completed the questionnaire for this study. Responses were anonymous and reviewed as the basis of the improvement of the next rubrics.

\section{Data Analysis}

The are six questions questionnaire represented three main conceptual construct' students process, student perception and student prediction.

1. How do rubrics help you know teacher's expectations?

2. How do rubrics help you plan for a better result?

3. How do you use rubrics in a process of completing assignment?

4. What are the impacts of rubrics in your ability to reflect on your work?

5. Do you think rubrics impact grading? Why or why not?

6. Do you think using rubrics affect the quality of your work? Why or why not?

Analysis of the questionnaire involved considering student comments in relation to the six of seven themes highlighted by Andrade and DU (2005) study discussed earlier: communicating teacher expectation, facilitating student planning, facilitating revision and reflection, resulting equitable grading and improving quality of work.

In the analysis, the six questions above were clustered into 2 groups. Questions number 1 through 4 address the construct of student process, specifically the way in which a student actively uses a rubric in doing a given assignment. Questions number 5 and 6 address student perceptions regarding the impact of using rubrics on their outcome and experience.

The analysis was done in four steps:

1. Examining responses to the 6 questions

2. Creating 2 categories of impact

3. Charting results based on the categories

4. Writing summary analysis

Each question was analyzed separately, so that all responses to each item were analyzed and grouped together. After the responses to each question were analyzed, the responses to questions $1-4$ and $5-6$ were grouped together to consider the constructs of process and perception.

\section{RESULTS AND DISCUSSIONS}

The students' responses to all questions regarding the impact of using rubric were positive and students thought that rubrics are important to their learning process, as well as their perceptions of assessment and learning in the classroom. Students also said that rubrics were helpful in completing their assignments and they expressed that rubrics informed them clearly about teacher expectation. The comparison of the result of their self assessment with the comment on the previous assignment gave them insight into how to find their weaknesses and focus on the points to improve.

Although most comments were positive, there is one concern area regarding rubrics as means of assessment. Students commented that for teachers, rubrics were really helpful in grading, however several students said that the description on each proficiency level on rubric were not helpful and grading was confusing. 


\section{Student Learning and Rubric}

The impact of rubric on student process and learning was the focus of questions $1-4$ of the questionnaire. These questions were asked to probe how rubrics give impact on students' engagement in the process of learning and completing their assignments.

\section{How do rubrics help you know teacher's expectations?}

Question 1 asked the students if rubrics provided them with a clear teacher's expectation on the assignment. All 34 students expressed that they got clear expectation regarding the assignment. They felt more secure about the important points necessary to get a good grade. Compared with the first assignment in which the students were not got the rubrics, several students commented that it was confusing to not know what important points to focus. However, 8 students commented that using rubrics bordered their creativities in which they could not write freely.

\section{How do rubrics help you plan for completing the assignment and get a better result?}

This point related to the responses of questions 2 and 3 of the questionnaire. All responses indicated that rubrics were tools for the students to help in planning and in production of the assignment. The criteria on the rubric help them in planning the draft of the assignment and the description on the proficiency level became the guidance in producing the writing assignment. Several students stated that they worked through the assignment by reading the rubric, while the others used it to check or review their assignment.

\section{What are the impacts of rubrics in your ability to reflect on your work?}

Question number 4 probed how rubrics played an important role in student reflection and revision. Responses indicated that this was not really an important role of the rubric, with 16 students responding that they did not use rubric to check their work until after the teacher distributed the result of the assignment and asked them to review it the find the reason of the grade. Nevertheless, the other students indicated that rubric was helpful in reflecting on their work before submitting it, with 4 students commenting that they made checklist based on the rubric to make sure they have done all the necessary points.

\section{Student Perception of Rubrics}

Questions 5 and 6 addressed two aspects of students'perceptions regarding outcomes relating to the use of rubrics: grades and quality of works.

\section{Do you think rubrics impact grading?}

Students indicated that rubric gave good impact on grading, but findings were different from Andrade and Du (2005) in that they did not see the impact as being primarily "Better, fairer grades" (p. 5), but instead getting good grade. Of the 34 responses, only 8 of them commented that using rubrics made the grading more objective. Most of them said that the impact here was related to how to get a god grade, and they commented that rubric was really helpful in this because they knew teacher's expectations, followed them and resulted in good grade.

\section{Do you think using rubrics affect the quality of your work?}

Question 6 asked the students if they felt rubrics influenced the quality of their works. All responses to this question were positive, especially when they had to compare their previous works in which they did them without rubrics. They felt they did better when they received rubrics before 
working on an assignment. Many of the comments reflected earlier statements regarding students' process addressed in questions $1-4$. The students stated that understanding teacher's expectation stated in the criteria is necessary in doing high quality works.

\section{Discussion}

Responses indicated that students use rubrics throughout the process of completing assignments and their view of rubrics is positive. This study supports Andrade and Du (2005) in their assertion that rubrics serve as tools for students. However in considering the role of rubrics in process and perception, some important themes are showed to indicate the feedback on the importance of rubrics in learning.

\section{Process}

Students said that they used rubrics to get the resource in the planning and completion of the assignment. If students think rubrics as a "checklist" of things they are required to do in completing the assignment and focus only on the criteria stated, the students may not gain mastery of the content. Using rubrics in this manner is not appropriate. In considering this use of rubrics, the teacher should focus too on how much each element of the rubric is used by the students. Moreover, to gain the thinking process of the students, the critical goals in learning should be added too as the criteria on the rubric.

The use of the rubric as a tool for reflection indicated that students did not consider the utility of the rubric for this purpose. This does not indicate a misconception so much as a point which could be emphasized to all students when using rubrics in the classroom. This indicates the understanding that for student, rubric is only a tool for assessment. The larger issue may be that the emphasis in classroom needs to be on formative assessment and students as "users" of assessment (Stiggins, 2001)

\section{Perception}

The use of rubric can increase communication between teacher and students. The transparency of rubrics in relation to the assessment cycle creates the perception for students that the teacher was willing to talk in specific about expectations and assessments throughout the learning process. Moreover, comments indicated students felt they could ask detailed questions regarding the given assignment and even the grading process. The positive advantages of the use of rubrics on teacherstudents communication should not be underestimated in creating positive learning and assessment environment.

\section{CONCLUSION}

This study was confirmatory and exploratory. It is really hoped that other study is sought to continue the discussion of how students use rubrics as a part of learning and assessment process. The use of self-report and limited data limits the ability to make recommendations. However the responses highlight the ways in which students use rubrics and the advantages of using them in the classroom. Students said that rubrics were really helpful in the process of doing the assignments and responses indicated areas in which the uses of rubrics could be emphasized during instruction to maximize the utilities. On the teacher side the feedback gathered based on the rubric may provide information regarding students' strengths and weaknesses. So, it is hoped that this can be focus points of the improvement of teaching materials and teaching strategies. 


\section{REFERENCES}

Andrade, H. G. (2000). Using rubrics to promote thinking and learning. Educational Leadership, 57(5).

Andrade, H. G. (2001). The effect of instructional rubrics on learning to write. Current issues in education Vol 4 (4). Available: http://cie.ed.asu.edu/volume4/number4

Andrade, H. G. \& Du, Y. (2005). Student perspective on rubric-referenced assessment. Practical Assessment Research and Evaluation, 10 (3). Available online: http://pareonline.net/getvn.asp? $\mathrm{v}=10 \& \mathrm{n}=3$

Brookhart, S. (2002). Development measurement theory for classroom assessment purposes and uses. Educational Measurement: Issues and Practice, 22 (4), 5-12.

Gregory, K., Cameron, C., \& Davies, A. (2000). Knowing what counts: Self-assessment and goalsetting. Courtenay, British Columbia: Connections Publishing.

Hafner, J.,\& Hafner, P. (2003). Quantitave analysis of the rubric as an assessment tool: An empirical study of the student peer-group rating. International Journal of Science Education, 25(12).

Stiggins, R.J. (2001). Student-involved classroom assessment ( ${ }^{\text {rd }}$ ed.). Upper Saddle River, NJ: Merrill/Prentice-Hall.

\section{APPENDIX}

Table 1 Sample writing assignment rubric

\begin{tabular}{|c|c|c|c|c|}
\hline \multirow[b]{2}{*}{ Criteria } & \multicolumn{4}{|c|}{ Proficiency Level } \\
\hline & Excellent & Very good & Good & Poor \\
\hline Focus & $\begin{array}{l}\text { Writing addresses } \\
\text { the assigned topic } \\
\text { thoroughly }\end{array}$ & $\begin{array}{l}\text { Writing addresses } \\
\text { the assignment } \\
\text { adequately }\end{array}$ & $\begin{array}{l}\text { Subject is clear but } \\
\text { the writing misses } \\
\text { some important } \\
\text { elements of } \\
\text { assigned topic }\end{array}$ & $\begin{array}{l}\text { Writing does not } \\
\text { address the assigned } \\
\text { topic and is large } \\
\text { unresponsive }\end{array}$ \\
\hline Use of examples & $\begin{array}{l}\text { Exceptional use of } \\
\text { related examples }\end{array}$ & $\begin{array}{l}1 \text { example is not } \\
\text { related to the topic }\end{array}$ & $\begin{array}{l}\text { Some examples are } \\
\text { related to the topic }\end{array}$ & $\begin{array}{l}\text { No suitable } \\
\text { examples related to } \\
\text { topic }\end{array}$ \\
\hline $\begin{array}{l}\text { Development of } \\
\text { argument }\end{array}$ & $\begin{array}{l}\text { Exceptionally well } \\
\text { developed ideas } \\
\text { with smooth } \\
\text { transition and } \\
\text { sophisticated } \\
\text { presentation }\end{array}$ & $\begin{array}{l}\text { Ideas are well } \\
\text { developed with } \\
\text { transitions and a } \\
\text { structured } \\
\text { presentation }\end{array}$ & $\begin{array}{l}\text { Sequence of ideas is } \\
\text { traceable although } \\
\text { paragraphing and } \\
\text { structure are wrong }\end{array}$ & $\begin{array}{l}\text { Essay is not } \\
\text { coherent, showing } \\
\text { little relationship } \\
\text { among the ideas }\end{array}$ \\
\hline Language & $\begin{array}{l}\text { Free from errors in } \\
\text { word choice and } \\
\text { grammar }\end{array}$ & $\begin{array}{l}\text { A few errors in } \\
\text { word choice and } \\
\text { grammar }\end{array}$ & $\begin{array}{l}\text { Accumulation of } \\
\text { errors in word } \\
\text { choice and grammar }\end{array}$ & $\begin{array}{l}\text { Serious and } \\
\text { persistent error in } \\
\text { word choice and } \\
\text { grammar }\end{array}$ \\
\hline
\end{tabular}

